\title{
Akuntabilitas Pelayanan Administrasi Kependudukan Di Kelurahan Purus Kota Padang
}

\author{
Ivoni Yona Melinda ${ }^{1}$, Asrinaldi ${ }^{2}$, Tengku Rika Valentina ${ }^{3}$
}

1Jurusan Ilmu Politik, Universitas Andalas, Indonesia. E-mail: ivoniyonamelinda@gmail.com

2Jurusan Ilmu Politik, Universitas Andalas, Indonesia. E-mail: asrinaldi4@gmail.com

3Jurusan Ilmu Politik, Universitas Andalas, Indonesia. E-mail: tengkurika@soc.unand.ac.id

\section{ARTICLE INFO}

Keywords: Public Service, Accountability, and service performance

Kata kunci: Pelayanan Publik, Akuntabilitas, dan Kinerja Pelayanan

How to cite:

Melinda, I. Y., Asrinaldi, \& Valentina, T. R. (2019).

Akuntabilitas

Pelayanan

Administrasi

Kependudukan di

Kelurahan Purus Kota Padang. JAKPP (Jurnal Analisis Kebijakan dan Pelayanan Publik), 5(2), 95-105.

\section{ABSTRACT}

The accountability used as one of the benchmarks of bureaucratic performance in public service organization context. In 2016, Purus village chosen as the best village in Padang. But there are still found the complaints to Purus village such as long service and complicated. The purpose of this thesis is to analyze and explain the accountability of public service in Purus village at 2016/2017. This thesis use qualitative method and descriptive. The technique of data collection are interview and documentation. In the selection of research informant, the researcher used purposive sampling technique. The result of this thesis show that the accountability of population administration service in Purus village but not maximal, Its because two of three indicators to see the accountability of public service that used maximal in Purus village, is For performance service indicator in Purus village, and accountability of product service indicator. For cost service, its still found take and give tradition that is not appropriate with the rules.

\begin{abstract}
Abstrak
Akuntabilitas digunakan sebagai salah satu tolak ukur kinerja birokrasi dalam konteks penyelengaraan pelayanan publik. Pada tahun 2016, Kelurahan Purus terpilih sebagai kelurahan berprestasi tingkat Kota Padang, namun masih ditemui adanya keluhan masyarakat terhadap Kelurahan Purus seperti pelayanan yang lama dan berbelit-belit. Tujuan dari penelitian ini adalah untuk menganalisis dan menjelaskan Akuntabilitas Pelayanan Kelurahan Purus tahun 2016/2017. Penelitian ini menggunakan metode kualitatif dengan tipe deskriptif. Teknik pengumpulan data dalam penelitian ini menggunakan teknik wawancara dan dokumentasi. Dalam pemilihan informan penelitian, peneliti menggunakan teknik purposive sampling. Hasil penelitian menunjukkan bahwa pelayanan administrasi kependudukan yang dilakukan di kelurahan Purus sudah belum terlaksana secara maksimal. Hal ini dikarenakan dari tiga indikator gunakan untuk melihat akuntabilitas pelayanan publik di Kelurahan Purus, dua indikator terlaksana dengan baik yaitu indikator akuntabilitas kinerja pelayanan, dan akauntabilitas produk pelayanan. Untuk indikator biaya pelayanan, masih ditemui budaya saling memberi dan menerima dalam pelayanan di Kelurahan Purus yang tidak sesuai dengan ketentuan yang ditetapkan.
\end{abstract}

Copyright @ 2019 JAKPP. All rights reserved.

\section{Pendahuluan}

Tantangan utama yang dihadapi pemerintah di manapun dalam bidang pelayanan publik bukan hanya untuk membuat bagaimana pelayanan publik berfungsi, efektif, efisien, dan fleksibel tetapi juga bagaimana membuatnya bertanggungjawab (akuntabel) dan dapat diakses oleh rakyat, dengan tujuan membuat pelayanan publik yang dilakukan 
memiliki orientasi kepada hasil, dan mampu memberikan pelayanan publik yang efektif, efisien dan akuntabel kepada masyarakat.1Pelayanan publik sebagaimana yang diatur dalam Undang-Undang No. 25 Tahun 2009 tentang Pelayanan Publik, menyatakan bahwa pelayanan publik merupakan hak setiap warga negara yang wajib dipenuhi negara karenanya negara berkewajiban melayani setiap warga negara dan penduduk untuk memenuhi hak dan kebutuhan dasarnya dalam kerangka pelayanan publik yang merupakan amanat Undang-Undang Dasar Negara Republik Indonesia Tahun 1945, dalam hal ini menurut Undang-Undang No. 25 Tahun 2009 Pelayanan Publik adalah kegiatan atau rangkaian dalam rangka pemenuhan kebutuhan pelayanan sesuai dengan peraturan perundang-undangan bagi setiap warga negara dan penduduk atas barang, jasa atau/dan pelayanan administratif yang disediakan oleh penyelenggara pelayanan publik. $^{2}$

Di Indonesia pelayanan publik yang diberikan oleh birokrasi cenderung mengarah ke stereotype negatif seperti berbelit-belit, tidak ramah, tidak adil, tidak transparan, mempersulit dan memperlama pelayanan, pungutan liar, suap dan sebagainya. ${ }^{3}$ Seperti hasil penelitian oleh Rina Martini, Nunik Retno, Dwi Purwandari (2013). ${ }^{4}$ Berdasarkan hasil penelitian sebelumnya peneliti berasumsi, terlalu lamanya menganut sistem pelayanan terpusat (sentralisasi) membuat para birokrat cenderung terpaku terhadap budaya birokrat terdahulu seperti budaya paternialistik, dimana mereka bekerja hanya mencari keuntungan untuk mereka sendiri dan cenderung bekerja untuk para atasan mereka (budaya ABS/ asal bapak senang), mereka hanya melihatkan professionalis dan semangat kerja hanya kepada atasan saja, sehingga tidak melayani masyarakat sebagaimana mestinya. Untuk terwujudnya suatu kinerja pelayanan publik oleh para birokrat yang baik, amanah dan demokratis pemerintah harus mampu melaksanakan dan mempertanggungjawabkan hasilnya kepada masyarakat sebagai penerima layanan (stakeholder). ${ }^{5}$ Untuk memperbaiki kinerja birokrasi maka perlulah pelaksanaan Good Governance (Tata Kelola Pemerintahan yang baik) dimana dalam menyelenggarakan pemerintah harus sesuai dengan prinsip-prinsip yang telah ditetapkan agar terwujud pemerintahan yang bersih dan akuntabel. ${ }^{6}$ Munculnya good governance merupakan

\footnotetext{
${ }^{1}$ Femi Omotoso. Public-Service Ethics and Accountability for Effective Service Delivery in Nigeria. Afrika today: Bloomington 60(3): 118-139. 2014. Hal 119. Diakses dari e-resources.perpunas.go.id pada 7 April pukul 13.40 WIB

${ }^{2}$ Lihat dalam UU No. 25 tahun 2009 Tentang Pelayanan Publik

3 : Rina martini. Birokrasi dan Politik. UPT UNDIP Press. Semarang. 2012. Hal 8

${ }^{4}$ Rina Martini, Nunik Retno dan Dwi Purwandari (2013), menyatakan sebagian besar jenis patologi yang terjadi diakibatkan birokrasi itu sendiri. Budaya birokrasi sejak jaman dahulu masih belum bisa dirubah oleh birokrasi itu sendiri. Dalam melakukan tugas sehari-seharinya banyak dari birokrasi yang belum maksimal dalam menjalankannya, terutama birokrasi yang berhubungan dengan pelayanan. Perubahan paradigma masih sangat diperlukan didalam birokrasi itu sendiri. Rujuk Rina Martini, Nunik Retno dan Dwi Purwandari. Patologi Birokrasi di Badan Kepegawaian Daerah Kabupaten Semarang. Jurnal Ilmu Pemerintahan 2(2). 2013. Diakses dari ejournal3.undip.ac.id pada Sabtu 12 Mei 2018 pukul 21.35 WIB

${ }^{5}$ Wedi Radian Dasril. Penerapan Prinsip Akuntabilitas Dalam Pelayanan Publik Di Pemerintahan Air Haji Kabupaten Pesisir Selatan. Skripsi S1 Ilmu Politik Universitas Andalas. 2015

${ }^{6}$ Good governance mencakup aspek kehidupan yang luas mulai dari aspek hukum, politik, ekonomi, sosial dan terkait erat dengan tugas fungsi eksekutif, legislatif dan yudikatif (state) serta dengan posisi dan peran sektor dunia usaha (private sector), dengan masyarakat (society). Dengan sembilan karteristik (menurut UNDP), yaitu
} 
tuntutan bagi perubahan kinerja pelayanan publik agar menghasilkan pelayanan publik yang berdayaguna dan berhasilguna, bersih dan bebas KKN (Korupsi, Kolusi dan Nepotisme), Akuntabilitas merupakan salah satu prinsip penting dalam Good Governance. Akuntabilitas digunakan sebagai salah satu tolak ukur dari kinerja birokrasi dalam konteks penyelengaaraan pelayanan publik.7 Dalam pelayanan publik akuntabilitas berarti bahwa pemerintah dan karyawannya (birokrat) bertanggungjawab atas kegiatan/pekerjaan mereka terbuka untuk umum (publik).

Untuk melihat akuntabilitas pelayanan publik ditingkat kelurahan, Kota Padang melakukan perlombaan kelurahan berprestasi dalam rangka untuk mengevaluasi perkembangan, kemajuan, kemandirian, keberlanjutan pembangunan, kesejahteraan masyarakat serta daya saing kelurahan, yang bertujuan untuk mengapresiasi bagi kelurahan yang telah berusaha menjalankan pemerintahan yang baik dan yang akuntabel kepada masyarakatnya. Pelaksanaan perlombaan kelurahan berprestasi tingkat Kota Padang berpedoman pada Peraturan Menteri Dalam Negeri Republik Indonesia Nomor 81 Tahun 2015 Tentang Evaluasi Perkembangan Desa dan Kelurahan.

Dengan terpilihnya Kelurahan Purus sebagai kelurahan berprestasi tingkat Kota Padang tahun 2016, namun masih ditemui masyarakat yang kurang puas terhadap pelayanan di Kelurahan Purus seperti pelayanan yang lama dan berbelit-belit. Dengan begitu peneliti berasumsi bahwa pelayanan publik di Kelurahan Purus belum maksimal, hal ini dikarenakan kinerja pelayanan di Kelurahan Purus belum terlaksana secara maksimal karena masih adanya pelayanan yang tidak sesuai dengan standar pelayanan Kelurahan Purus yaitu waktu pelayanan tidak sesuai dengan standar pelayanan Kelurahan Purus. Untuk biaya pelyanan masih ditemui adanya budaya saling memberi dan menerima dalam pelayanan yang sesuai dengan aturan yang ditetapkan. Sedangkan untuk produk pelayanan yang dihasilkan Kelurahan Purus sudah diterima dengan cukup baik. Berdasarkan masalah tersebut maka muncullah pertanyaan penelitian yaitu bagaimana Akuntabilitas Pelayanan Kelurahan Purus tahun 2016/2017 (sebagai Kelurahan Berprestasi Tingkat Kota Padang Tahun 2016)?. Adapun tujuan dari penelitian ini ada untuk menganalisis dan menjelaskan Akuntabilitas Pelayanan Kelurahan Purus tahun 2016/2017 (sebagai Kelurahan Berprestasi Tingkat Kota Padang Tahun 2016)

participation, rule of law, transparency, responsiveness, consensus orientation, equity, effectiveness \& efficiency, accountability and strategic vision. Ini merupakan syarat utama dalam pelaksanaan tata kelola pemerintahan yang baik (good governance), prinsip ini tidak hanya berlaku terhadap instansi pemerintah saja tetapi juga terhadap sektor swasta dan organisasi masyarakat sipil lainnya. Penerapan prinsip-prinsip good governance dalam praktik pelayanan publik dianggap bisa memperbaiki pelayanan publik di Indonesia ini. Sumber: modul LAN\&BPKP. 2000. Akuntabilitas dan Good Governance. Hal. 19

${ }^{7}$ Dengan akuntabilitas diartikan bahwa suatu instansi telah menetapkan dan mempunyai visi, misi, tujuan serta sasaran, yang jelas terhadap program kerja yang telah, sedang atau akan dijalani. Dengan akuntabilitas juga akan dapat diukur bagaimana mereka menyelenggarakan/menjalankan dan memeprtahankan tanggungjawab mereka terhadap pencapaian hasil. Rujuk Wedi Radian Dasril. Penerapan Prinsip Akuntabilitas Dalam Pelayanan Publik Di Pemerintahan Air Haji Kabupaten Pesisir Selatan. Skripsi S1 Ilmu Politik Universitas Andalas. 2015. Untuk pembahasan lebih lanjut. 


\section{Tinjauan Pustaka}

\section{Konsep Akuntabilitas}

Akuntabilitas merupakan salah satu prinsip dalam Good Governance. Gaffar (dalam Napitupulu P), akuntabilitas adalah tanggungjawab segenap kebijakan, tindakan dan tutur kata, serta perilaku yang pernah, sedang dan akan dilaksanakan oleh pemegang jabatan yang dipilih oleh rakyat. ${ }^{2}$ Taliziduhu Ndraha mengemukakan bahwa akuntabilitas adalah kemampuan untuk menjawab atau memenuhi janji atau komitmen, baik janji kepada orang lain maupun janji kepada diri sendiri. Tanggung jawab merupakan salah satu mata rantai yang menghubungkan janji dan yang menghubungkan janji dan percaya dalam hubungan pemerintah. ${ }^{9}$ Sedangkan menurut Lenvine, akuntabilitas adalah suatu ukuran untuk menunjukkan seberapa besar tingkat kesesuaian antara penyelenggara pelayanan dengan ukuran-ukuran eksternal yang ada dimasyarakat dan dimiliki oleh stakeholders, seperti nilai dan norma yang berkembang dalam masyarakat.

Akuntabilitas yaitu aparat pemerintah itu mempunyai tugas memberikan pelayanan yang sebaik-baiknya dan dapat mempertanggungjawabkan pada masyarakat. Sedangkan menurut UNDP akuntabilitas merupakan setiap aktivitas yang berkaitan dengan kepentingan publik perlu mempertanggungjawabkan kepada publik. Tanggung gugat dan tanggung jawab tidak hanya diberikan kepada atasan saja tapi juga pada para pemegang saham (stakeholder) yaitu masyarakat luas. ${ }^{10}$ Jadi dapat disimpulkan bahwa akuntabilitas adalah bentuk pertanggungjawaban seseorang baik itu kepada atasan maupun kepada masyarakat (stakeholder). Karena setiap kegiatan yang kita lakukan harus dapat dipertanggungjawabkan hasilnya kepada pemberi tugas.

\section{Konsep Pelayanan Publik}

Secara sederhana pelayanan publik dapat dimaksud dengan pelayanan terhadap umum/publik. Pelayanan publik diartikan sebagai pemberian layanan (malayani) keperluan orang atau masyarakat yang mempunyai kepentingan pada organisasi itu sesuai dengan aturan pokok dan tata cara yang telah ditetapkan. ${ }^{11}$ Sedangkan menurut Undang-Undang No. 25 Tahun 2009 Tentang Pelayanan Publik mendefinisikan pelayanan publik adalah kegiatan atau rangkaian kegiatan dalam rangka pemenuhan kebutuhan pelayanan sesuai dengan peraturan perundang-undangan bagi setiap warga negara dan penduduk atas barang, jasa, dan/ atau pelayanan administratif yang disediakan oleh penyelenggara pelayanan publik.

Sedangkan Ratminto dan Winarsih mendefinisikan pelayanan publik sebagai segala bentuk jasa pelayanan, baik dalam bentuk barang publik maupun jasa publik yang pada prinsipnya menjadi tanggungjawab dan dilaksanakan oleh instansi pemerintahan di Pusat, di Daerah maupun di lingkungan Badan Usaha Milik Negara atau Badan Usaha

\footnotetext{
${ }^{8}$ Paimin Napitupulu. Pelayanan Publik dan Customer Satisfaction. Pt. Alumni. Bandung. 2014. Hal. 50

${ }^{9}$ Ibid. Hal. 64

${ }^{10}$ Utang Rosidi. Otonomi Daerah dan Desentralisasi. CV Pustaka Setia. Bandung. 2010 Hal 182

${ }^{11}$ Ismail, dkk. Menuju Pelayanan Prima: Konsep Dan Strategi Peningkatan Kualitas Pelayanan Publik. Program Sekolah Demokrasi (cetakan I). 2010. Hal. 85
} 
Milik Daerah, dalam rangka upaya pemenuhan kebutuhan masyarakat maupun dalam rangka pelaksanaan ketentuan peraturan perundang-undangan. ${ }^{12}$

Jadi dari beberapa pendapat diatas dapat disimpulkan bahwa pelayanan publik adalah serangkaian kegiatan pelayanan yang diberikan oleh pelaksana pelayanan kepada publik/masyarakat sesuai dengan prinsip dan aturan yang telah ditetapkan, baik itu pelayanan administrasi, pelayanan barang maupun pelayanan jasa.

\section{Akuntabilitas Pelayanan Publik}

Dengan pengertian secara luas, akuntabilitas pelayanan publik berarti pertanggungjawaban pegawai pemerintah kepada publik yang menjadi konsumen pelayanan. ${ }^{13}$ Berdasarkan Keputusan Menteri Pendayagunaan Aparatur Negara Nomor KEP/26/M.PAN/2/2004 Tanggal 24 Februari 2004 Tentang Teknik Transparansi dan Akuntabilitas Penyelenggara Pelayanan Publik, penyelenggara pelayanan publik harus dapat dipertanggungjawabkan, baik kepada publik maupun kepada atasan atau pemimpin unit pelayanan instansi pemerintahan sesuai dengan ketentuan perundangundangan. Untuk mengukur akuntabilitas penyelenggaraan pelayanan publik dalam penelitian dilihat melalui bentuk pertanggungjawaban pelayanan publik menurut Ratminto dan Winarsih Winarsih yang meliputi diantaranya: ${ }^{14}$

Akuntabilitas kinerja pelayanan publik meliputi: (a) Akuntabilitas kinerja pelayanan publik dapat dilihat berdasarkan proses yang antara lain meliputi: tingkat ketelitian (akurasi), profesionalitas petugas, kelengkapan sarana dan prasarana, kejelasan aturan (termasuk kejelasan kebijakan atau peraturan perundang-undangan) dan kedisiplinan, (b) Akuntabilitas kinerja pelayanan publik harus sesuai dengan standar pelayanan publik yang telah ditetapkan, (c) Standar pelayanan publik harus dapat dipertanggungjawabkan secara terbuka, baik kepada publik maupun kepada atasan atau pimpinan unit pelayanan instansi pemerintah. Apabila terjadi penyimpangan dalam hal pencapaian standar, maka harus dilakukan perbaikan, (d) Penyimpangan yang terkait dengan akuntabilitas kinerja publik harus diberikan kompensasi kepada penerima pelayanan, (e) Masyarakat dapat melakukan penelitian terhadap kinerja pelayanan secara berkala sesuai mekanisme yang berlaku, (f) Disediakan mekanisme pertanggungjawaban bila terjadi kerugian dalam pelayanan publik, atau jika pengaduan masyarakat tidak mendapat tanggapan sesuai waktu dengan waktu yang telah ditentukan.

Akuntabilitas Biaya Pelayanan Publik meliputi: (a) Biaya pelayanan dipungut sesuai dengan ketentuan peraturan perudang-undangan yang telah ditetapkan, (b) Pengaduan masyarakat yang terkait dengan penyimpangan biaya pelayanan publik, harus ditangani oleh petugas/pejabat yang ditunjuk berdasarkan Surat Keputusan/Surat Penugasan dari pejabat yang berwenang. Akuntabilitas Produk Pelayanan Publik meliputi: (a) Persyaratan teknis dan administratif harus jelas dan dapat dipertanggungjawabkan dari segi kualitas dan keabsahan produk pelayanan, (b) Prosedur dan mekanisme kerja harus

\footnotetext{
${ }^{12}$ Ratminto dan Atik Septi Winarsih. Manajemen Pelayanan : Pengembangan Model Konseptual, Penerapan Citizen's Charter dan Standar Pelayanan Minimal. Yogyakarta: pustaka pelajar. 2005. Hal. 5

${ }^{13}$ Op.cit, Modul LAN\&BPKP. 2000. Hal. 22

${ }^{14}$ Op.cit. Ratminto dan Winarsih. 2005. Hal. 216-218
} 
sederhana dan dilaksanakan sesuai dengan ketentuan yang telah ditetapkan, (c) Produk pelayanan diterima dengan benar, tepat dan sah.

\section{Metode Penelitian}

Pendekatan penelitian yang digunakan adalah pendekatan kualitatif dengan tipe deskriptif. Lokasi penelitian adalah di Kelurahan Puru, Kecamatan Padang Barat, Kota Padang, Sumatera Barat, Indonesia. Dalam penelitian ini Teknik pengumpulan data berupa data primer dan data sekunder. Data primer diadapatkan dari wawancara dengan informan yaitu Lurah, Sekretaris lurah, Kasi-kasi di Kelurahan, Camat Padang Barat dan Masyarakat yang menerima pelayanan. Teknik pemilihan informan diambil secara purposive sampling. Sedangkan data sekunder didapat dari dokumentasi. Analisis data dilakukan dengan menggunakan model interaktif yang dikemukakan oleh Miles dan Huberman (2014)

\section{Hasil dan Pembahasan}

\section{Akuntabilitas Kinerja di Kelurahan Purus}

Berdasarakan dengan hasil wawancara dengan beberapa informan dan triangulasi, peneliti berpendapat bahwa akuntabilitas kinerja pelayanan di Kelurahan Purus sudah cukup berakuntabilitas karena dari lima sub indikator yang peneliti gunakan untuk melihat akuntabilitas pelayanan publik di Kelurahan Purus, tiga sub indikator sudah terlaksana dengan baik dan dua sub indikator belum terlaksana dengan baik. Di mana tiga sub indikator tersebut yaitu proses pelayanan (yang meliputi tingkat ketelitian, tingkat professional, kejelasan aturan, sarana dan prasarana, serta kedisiplinan), masyarakat dapat melakukan penilaian kinerja aparatur pelayanan dan mekanisme serta kejelasan waktu pengaduan. Dua poin yang belum terlaksana maksimal yaitu standar pelayanan dan pertanggungjawaban terhadap standar pelayanan, berikut uraiannya:

1. Proses pelayanan

a. Tingkat ketelitian (akurasi)

Tingkat ketelitian dalam pelayanan administrasi yang diberikan kepada masyarakat sudah cukup telaksanakan dengan baik itu terbukti saat melakukan proses pelayanan aparatur/kasi-kasi yang bersangkutan terlebih dahulu memeriksa kelengkapan syarat-syarat pelayanan dari masyarakat dan saat melakukan proses pelayanannya pun aparatur/kasi-kasi yang bersangkutan juga memeriksa kembali data-data masyarakat guna untuk meminimalisir kesalahan ketik saat produk pelayanan sudah jadi nantinya.

b. Tingkat profesional

Tingkat profesional aparatur kelurahan di sini dapat dilihat dari segi penguasaan prasarana yang digunakan dalam pelayanan seperti komputer dan printer, di mana profesional aparat Kelurahan Purus didukung oleh salah satunya faktor pendidikan yang dimiliki aparatur kelurahan dimana mereka rata-rata tamatan sarjana sehingga bisa melayani masyarakat dengan 
baik dan dituntut untuk bisa melakukan pelayanan yang di mana-mana sekarang berbasis teknologi. Kedua, dari segi bertanggungjawab dalam melaksanakan tugasnya, di mana dalam memberikan pelayanan kasi-kasi di Kelurahan Purus memiliki tugas dan tanggungjawab masing-masing, namun mereka sesama kasi (Kepala Seksi) dapat saling membantu tugas masing-masing. Jika kasi yang bersangkutan berhalangan hadir demi tidak terbengkalainya pelayanan kepada masyarakat.

Ketiga, dari segi sikap aparatur saat memberikan pelayanan, dalam melakukan pelayanan sikap aparatur kelurahan Purus cukup baik karena berdasarkan temuan di lapangan, sebagian masyarakat sebagai triangulasi menyatakan dalam memberikan pelayanan aparatur kelurahan bersikap ramah dan sopan kepada masyarakat.

c. Sarana dan prasarana

Dari segi kelengkapan sarana dan prasarana di Kelurahan Purus sudah terlaksana dengan baik, terlihat dalam mendukung berjalannya proses pelayanan itu terlihat dari letak kantor yang mudah diakses oleh masyarakat Purus, kondisi gedung yang masih bagus dan kokoh, adanya ruang-ruang bagi aparatur kelurahan yang membuat mereka bisa melakukan pekerjaan mereka dengan nyaman, adanya ruang tunggu yang dilengkapi TV yang membuat masyarakat yang melakukan pelayanan nyaman dalam menunggu atau melakukan pelayanan, adanya papan informasi, kotak kepuasan dan saran bagi masyarakat yang puas atau tidak puas dengan pelayanan yang di berikan serta juga bagi masyarakat yang ingin memberikan saran kepada kelurahan, serta kelengkapan peralatan yang digunakan dalam pelayanan seperti komputer, printer, mesin tik (jika diperlukan), serta juga ada ruang serba serbi yang bisa digunakan jika ada acara di kelurahan maupun untuk rapat di kelurahan. Adanya kelengkapan sarana prasarana merupakan penunjang berjalannya proses pelayanan karena proses pelayanan tidak akan berjalan tanpa adanya sarana dan prasarana yang mendukung.

d. Kejelasan aturan

Aturan yang jelas merupakan acuan bagi aparatur kelurahan Purus dalam menjalankan tugasnya. Dari hasil wawancara peneliti berpendapat jika dalam melayani masyarakat di Kelurahan Purus aparatur kelurahan sudah memiliki aturan yang menggatur atau tupoksinya masing-masing. Di mana dalam melakukan tugasnya mereka memiliki tanggungjawab masingmasing yang semua tercantum dalam Keputusan Walikota Padang Nomor 93 Tahun 2016 tentang Kedudukan, Susunan Organisasi, Tugas, Fungsi, dan Tata Kerja.

e. Kedisiplinan

Kedisiplinan aparatur kelurahan Purus cukup baik hal ini dikarenakan masyarakat yang melakukan pelayanan di Kelurahan Purus menyatakan 
bahwa aparatur kelurahan Purus ada terus dan selalu melayani masyarakat yang ingin melakukan pelayanan. Meskipun masyarakat menerima pelayanan dengan baik di kelurahan, namun dari lurahnya sendiri kedisiplinan aparatur di Kelurahan Purus masih perlu ditingkatkan karena kadang masih adanya aparatur kelurahan yang datang terlambat karena adanya urusan lain namun karena semua aparatur kelurahan bisa melakukan pelayanan kepada masyarakat. Hal ini menunjukkan adanya kesadaran dari kelurahan sendiri untuk lebih meningkatkan tingkat kedisiplinan aparatur kelurahan.

\section{Standar Pelayanan}

Kelurahan Purus memiliki standar pelayanan yaitu SOP (Standar Operasional Pelayanan) namun standar pelayanan di Kelurahan Purus belum terlaksana dengan maksimal. Hal ini terbukti dengan masih adanya beberapa jenis pelayanan yang tidak termuat dalam SOP (Standar Operasional Pelayanan) seperti surat pengantar kematian, surat keterangan masih hidup, surat izin usaha, pengantar untuk modal usaha, rekomendasi tempat usaha, keterangan datang, keterangan pindah, izin keramaian, permohonan BPJS. Sehingga membuat adanya beberapa pelayanan yang tidak jelas dan mengharuskan masyarakat menanyakan langsung kepada aparatur kelurahan terkait pelayanan yang tidak jelas atau tidak mereka ketahui syarat-syarat pelayanannya, dan juga tidak memuat biaya pelayanan ke dalam SOPnya. Juga masih ditemui adanya pelayanan yang tidak sesuai waktu pelayanan yang telah ditetapkan seperti beberapa kasus di atas seperti pengurusan surat keterangan miskin, akte kelahiran dan SKCK yang harusnya selesei 10 menit tapi malah selesai besoknya atau satu hari.

3. Standar pelayanan harus dapat dipertanggungjawabkan, baik ke atasan maupun kepada masyarakat dan apabila terjadi penyimpangan dalam pencapaian standar pelayanan maka perlu perbaikan atau evaluasi

Mekanisme pertanggungjawaban kinerja terhadap standar pelayanan di Kelurahan Purus tidak terbuka karena sesuai dengan fakta di lapangan yang peneliti temui, aparatur Kelurahan Purus hanya mempertanggungjawabkan hanya terjadi secara hirarki kepada atasan saja (yaitu secara internal kelurahan kasi-kasi kelurahan bertanggungjawab kepada Sekretaris Lurah dan Sekretaris Lurah bertanggungjawab kepada Lurah dan Lurah bertanggungjawab kepada Camat) serta tidak mempertanggungjawabkan capaian kinerjanya terhadap standar pelayanan kepada publik (masyarakat).

Selain pelayanan publik harus berjalan sesuai dengan standar pelayanan yang telah ditetapkan. Juga mencakup apabila terjadi penyimpangan dalam pencapaian standar pelayanan maka perlu perbaikan atau evaluasi. Berdasarkan hasil temuan, peneliti menilai bahwa untuk meningkatkan kinerja aparatur Kelurahan Purus secara internal berusaha untuk meningkatkan pelayanan publik agar lebih maksimal yaitu dengan mengevaluasi kinerja aparatur kelurahan secara berkala setiap bulannya guna untuk memantau apakah kinerja 
yang dilakukan sesuai atau sejalan dengan seharusnya dalam mencapai tujuan yang diharapkan.

4. Masyarakat dapat melakukan penilaian terhadap kinerja pelayanan

Dari Kelurahan Purus sendiri sudah berusaha terbuka menerima pendapat/tanggapan/saran/pengaduan dengan menyediakan kotak kepuasan dan kotak saran bagi masyarakat yang ingin menilai kinerja aparatur kelurahan. Karena kepuasan masyarakat merupakan tujuan utama dalam pelayanan publik di Kelurahan Purus sehingga dengan adanya kotak kepuasan dan saran menjadi evaluasi bagi aparatur kelurahan sendiri dalam meningkatkan pelayanan publik di Kelurahan Purus.

5. Disediakan mekanisme pertanggungjawaban bila terjadi kerugian dalam pelayanan publik atau jika pengaduan masyarakat tidak mendapat tanggapan sesuai dengan waktu yang telah ditentukan.

Mekanisme pengaduan di Kelurahan Purus di mana aparatur kelurahan menerima pengaduan dari masyarakat terkait kinerja aparaturnya baik pengaduan secara tertulis maupun secara lisan. Berdasarkan hasil wawancara, dapat dilihat bahwa pelayanan yang diberikan aparatur kelurahan Purus sudah cukup baik. Di mana masyarakat cukup puas dengan pelayanan yang di berikan oleh aparatur Kelurahan Purus ini dibuktikan dengan tidak adanya pengaduan mengenai buruknya kinerja aparatur Kelurahan Purus kepada masyarakat. ${ }^{15}$

\section{Akuntabilitas Biaya Pelayanan}

Berdasarkan hasil wawancara dengan informan dan triangulasi, peneliti menilai akuntabilitas biaya pelayanan di Kelurahan Purus belum terlaksana secara maksimal karena karena masih ditemui budaya saling memberi dan menerima menyangkut biaya pelayanan dan itu tidak sesuai dengan aturan yang ditetapkan yaitu sesuai aturannya semua pelayanan di Kantor Kelurahan Purus gratis. Maka disini perlunya penegasan baik kepada aparatur pelayanan maupun masyarakat mengenai biaya pelayanan, dan penegasan untuk mentaati peraturan yang sudah ditetapkan terkait biaya pelayanan. Serta untuk pengaduan mengenai penyimpangan biaya yang dilakukan oleh aparatur Kelurahan Purus tidak ada. Karena dari aparaturnya sendiri tidak ada meminta uang tambahan saat pelayanan, tapi masyarakatnya sendiri yang memberi uang kepada aparatur sebagai ucapan terimakasih karena telah membantu urusan mereka.

\section{Akuntabilitas Produk Pelayanan}

Akuntabilitas produk pelayanan di kelurahan Purus sudah cukup berakuntabilitas. Hal ini terbukti dengan ketiga sub indikator yang peneliti gunakan untuk melihat akuntabilitas produk pelayanan sudah cukup terlaksana dengan baik di Kelurahan Purus, dari tiga sub indikator tersebut hanya satu sub indikator yang belum terlaksana dengan baik yaitu persyaratan teknis dan administratif harus jelas dan dapat dpertanggungjawabkan dari segi kualitas dan keabsahan produk pelayanan, berdasarkan 
temuan masih adanya beberapa jenis produk pelayanan yang tidak diinformasikan jelas dalam SOP (Standar Operasional Pelayanan) Kelurahan Purus seperti: surat pengantar kematian, surat keterangan masih hidup, surat izin usaha, pengantar untuk modal usaha, rekomendasi tempat usaha, keterangan datang, keterangan pindah, izin keramaian, permohonan BPJS..

Sedangkan dua sub indikator yang terlaksana dengan baik yaitu prosedur dan mekanisme kerja harus sederhana dan dilaksanakan sesuai dengan ketentuan yang telah ditetapkan, dan produk pelayanan diterima dengan benar, sah dan tepat. Serta dengan tidak adanya masalah mengenai produk pelayanan yang dihasilkan Kelurahan Purus itu menunjukkan bahwa dari segi produk pelayanan Kelurahan Purus sudah cukup bertanggungjawab.

\section{Kesimpulan}

Akuntabilitas pelayanan publik bidang administrasi kependudukan yang dilakukan di Kelurahan Purus belum berjalan secara maksimal. Hal ini dikarenakan masih terdapat kelemahan-kelemahan dari kelurahan Purus dalam memberikan pelayanan kepada masyarakat. Misalnya Akuntabilitas Kinerja pelayanan masih terdapat kekurangan yaitu berupa standar operasional pelayanan yang tidak terdapat di kelurahan yaitu: surat pengantar kematian, surat keterangan masih hidup, surat izin usaha, pengantar untuk modal usaha, rekomendasi tempat usaha, keterangan datang, keterangan pindah, izin keramaian, permohonan BPJS. Serta juga tidak mencantumkan biaya pelayanan di dalam SOP tersebut. Juga ditemukan pelayanan yang selesai tidak sesuai dengan waktu pelayanan yang ditetapkan. Sedangkan untuk akuntabilitas biaya pelayanan belum berjalan maksimal, hal ini di karenakan biaya pelayanan tidak diinformasikan secara tertulis dan tidak dipajang di kantor kelurahan sehingga membuat tidak adanya kejelasan mengenai biaya pelayanan. Juga masih ditemukan budaya saling memberi dan menerima antara aparatur pelayanan dengan masyarakat dalam pelayanan karenanya perlu tindakan yang tegas kepada aparatur pelayanan maupun masyarakat mengenai kejelasan biaya pelayanan sesuai dengan aturan yang telah ditetapkan.

\section{Saran}

Akuntabilitas pelayanan publik bidang administrasi kependudukan di Kelurahan Purus belum berjalan maksimal sehingga diperlukan saran dan rekomendasi sebagai berikut ini; (1) Untuk aparatur Kelurahan Purus perlu adanya peningkatan kinerja pelayanan dan tanggungjawab dalam melaksanakan tugas yang telah diberikan. (2) Kelurahan Purus perlu membuat lebih detail Standar Operasional Setiap jenis-jenis pelayanan di kelurahan Purus agar jelas dipahami oleh masyarakat dan menjalankan pelayanan sesuai dengan standar yang telah ditetapkan tersebut. (3) Dibuatkan spanduk atau banner untuk setiap jenis pelayanan dan biaya yang dibebankan di Kelurahan Purus.. 
Volume 5 No. 2, Desember 2019

pISSN: 2460-6162. eISSN: 2527-6476

\section{Daftar Pustaka}

Dwiyanto, Agus. Partini. Ratminto. Bambang Wicaksono. Wini Tamtiari. Bevaola Kusumasari. Mohammad Nuh. 2006. Reformasi Birokrasi Publik di Indonesia. Yogyakarta: Gajah Mada University Press.

Femi Omotoso. 2014. Public-Service Ethics and Accountability for Effective Service Delivery in Nigeria. Afrika today: Bloomington 60(3): 118-139. Diakses dari eresurce.perpunas.go.id

Ismail. Immanuel Yosua. M Khoirul Anwar. Syamsud Dhuha. 2010. Menuju Pelayanan Prima, Konsep dan Strategi Peningkatan Kualitas Pelayanan Publik. Program Sekolah Demokrasi.

Miles, Matthew B.; Huberman, A. Michael; Saldaña, Johnny. (2014). Qualitative Data Analysis: A Methods Sourcebook (3 ed.). (M. B. Miles, A. M. Huberman, \& J. Saldaña, Eds.) Thousand Oaks, CA: Sage Publications.

Modul LAN\&BPKP. 2000. Akuntabilitas dan Good Governance.

Moleong, Lexy J. 2014.Metodologi Penenlitian Kualitatif. Bandung: P.T. Remaja Rosdakarya.

Napitupulu, Paimin. 2014. Pelayanan Publik dan Customer Satisfaction. Bandung: Pt. Alumni.

Pemendagri Nomor 81 Tahun 2015 Tentang Evaluasi Perkembangan Desa dan Kelurahan

Ratminto \& Atik Septi Winarsih. 2005. Manajemen Pelayanan: Pengembangan Model Konseptual, Penerapan Citizen's Charter dan Standar Pelayanan Minimal. Yogyakarta: Pustaka Pelajar.

Rina Martini, Nunik Retno dan Dwi Purwandari. 2013. Patologi Birokrasi di Badan Kepegawaian Daerah Kabupaten Semarang. Jurnal ilmu pemerintahan 2(2). Diakses dari ejournal3.undip.ac.id

Rina martini. 2012. Birokrasi dan Politik. UPT UNDIP Press. Semarang.

Rosidi, Utang. 2010. Otonomi Daerah dan Desentralisasi. Bandung: CV Pustaka Setia.

Sugiyono. 2013. Metode Penelitian Kualitatif Kuantitatif dan RED. Bandung: Alfabeta.

Sukandrumidi. 2012. Metedologi Penelitian: Petunjuk Praktis Untuk Peneliti Pemula. Yogyakarta: Gajah Mada University Press.

Suyanto, Bagong dan Sutinah. 2007. Metode Penelitian Sosial. Jakarta: Kencana

UU RI Nomor 25 Tahun 2005 Tentang Pelayanan Publik

Wedi Radian Dasril. Penerapan Prinsip Akuntabilitas Dalam Pelayanan Publik Di Pemerintahan Air Haji Kabupaten Pesisir Selatan. Skripsi S1 Ilmu Politik Universitas Andalas. 2015 